Glacial-thrust terrain formed where the glacier was frozen to the substrate and where elevated pore-water pressure decreased the shear strength of the substrate to a value less than that applied by the glacier. The marginal zone of ice sheets consisted of a frozen-bed zone, no more than 2 to $3 \mathrm{~km}$ wide in places, within which glacial-thrust blocks are large and angular. Up-glacier from this zone, the thrust blocks are generally smaller and smoothed. Streamlined terrain begins 2 to $3 \mathrm{~km}$ behind known ice-margin positions and extends tens of kilometres up-glacier. Streamlined terrain formed in two ways: (I) erosion of the substrate as a consequence of basal sliding in the sub-marginal thawed-bed zone and (2) erosional smoothing accompanied by emplacement of till in the lee of thrust blocks where they were deposited and subsequently exposed to thawed-bed conditions as a result of further advance of the glacier.

This paper has been accepted for publication in full in a future issue of the Fournal of Glaciology.

\title{
EROSION OF GROOVES BY SUBGLACIAL MELT-WATER STREAMS
}

\author{
By I. M. Whillans \\ (Department of Geology and Mineralogy, and Institute of Polar Studies, Ohio State \\ University, Columbus, Ohio 432 Io, U.S.A.)
}

Abstract. The shape of the former Laurentide ice sheet in what is now northern Ohio and southern Ontario is calculated and the subglacial hydrological potential field computed. Subglacial water flow is found to be concentrated over high points in the bed, such as what is now Kelleys Island in Lake Erie. Some $10^{10}$ litres of subglacial melt water per year passed over Kelleys Island.

It is argued that the "glacial" grooves on Kelleys Island are subglacial melt-water channels. Assuming that the subglacial melt water attained saturation with respect to $\mathrm{CaCO}_{3}$ in passing over the limestone of Kelleys Island, the material formerly occupying the grooves could have been dissolved in $\mathrm{IO}^{2}$ years. This is a much shorter time than glacier occupancy and the assumption of chemical equilibrium is not critical.

The features on Kelleys Island are fluted valleys about $6 \mathrm{~m}$ across and each flute is about o. $1 \mathrm{~m}$ in width. Each flute represents a subglacial channel but only one or two of these channels operated at any one time. Blockages, perhaps caused by basal debris, caused the rivers to make minor course changes and in many instances it is possible to determine the order of channel occupancy. The channels were striated after abandonment by water when moving basal debris or debris-laden ice occupied the channels. From the Gauckler-Manning formula and the potential gradient obtained from the ice-sheet model the river velocity is calculated to be about $4 \mathrm{~m} \mathrm{~s}^{-1}$, in rough agreement with the water flux calculated earlier.

The grooves support the concept that subglacial water flows in "Nye" channels, and raise the suggestion that subglacial erosion by solution is of widespread importance.

\section{DISGUSSION}

C. R. Bentley: In producing the surface elevations for your reconstructed ice sheet you have apparently integrated the expression for $\mathrm{d} E / \mathrm{d} l$ down-stream so that there is no up-stream expression of Kelleys Island. If you approached from down-stream instead you would, I 
believe, get an up-stream ridge. The true situation should show aspects of both an up-stream ridge and a down-stream valley. Have you considered this for the hydrologic potential? It would seem that a ridge would force water to diverge around the island.

I. M. Whillans: You are correct about the importance of the direction of integration for the first iteration. The model is intended only to provide a rough description of ice and water movement. Implicit in my approach are the assumptions that Kelleys Island does not affect the general ice flow in a major way and the ice flow does not "see" Kelleys Island before it comes to it. The effects of longitudinal stress gradients are comparatively small and I think that the assumptions are fair. Certainly the resulting ice-sheet form is in qualitative agreement with what we observe on glaciers today. An up-stream ridge due to the longitudinal stress gradients would cause water to be diverted somewhat, but this water could subsequently be collected in the lee of the obstruction as I have shown.

S. R. Moran: The solution mechanism proposed appears to require very long travel of water over sediment and rock containing $\mathrm{CaCO}_{3}$. Then in a few kilometres across Kelleys Island it dissolves abundant carbonate. Have you considered the physical (chemical) probability of the efficacy of the proposed solution mechanism?

Whillans: In view of the wide range in $\mathrm{Ca}^{++}$concentration reported in the literature, such a calculation would not affect the argument. Even with solution rates of $\mathrm{I} / \mathrm{I} O \mathrm{or} \mathrm{I} / \mathrm{I} 00$ of what I used, subglacial water could have dissolved that much limestone.

G. S. Boulton: You suggest a water velocity in the grooves of $6 \mathrm{~m} \mathrm{~s}^{-1}$. How does water travelling so rapidly fail to transport boulders, which are so abundant in the area, and fail to produce forms typical of boulder transport in fast-moving glacier streams?

Why do you rule out glacial abrasion, when most of the features you describe are so typical of glacial abrasion by "streamed" basal debris? Why are signs of limestone solution so singularly lacking?

The water-flow theory which you have used to assess the water discharge around Kelleys Island is appropriate to a glacier resting on a stable impermeable bed. Are not water-flow patterns in the Lake Erie area likely to have been largely controlled by the changing hydrogeology of the substratum.

Whillans: I find that erosion by solution is sufficient. Other mechanisms can also operate, and I invoke glacial abrasion to produce the striae. Perhaps this abrasion smoothed the solution pits.

The hydro-geology of the substrate would affect water flow. My concern here is to calculate the water potential field which drives the flow.

\title{
THE ICE-ROGK INTERFAGE FOR THE GLIMAP I 8000 YEARS B.P. AND I 20 ooo YEARS B.P. EXPERIMENTS
}

\author{
By $\mathrm{T}$. J. Hughes
}

(Department of Geological Sciences and Institute of Quaternary Studies, University of Maine, Orono, Maine 04473, U.S.A.)

Abstract. Most numerical models of present ice-sheet dynamics predict basal thermal conditions for an assumed geothermal heat flux and measured ice thickness, surface temperature, and snow precipitation. These models are not ideally suited for reconstructing former ice 